\title{
CORRIGENDUM
}

\section{Intraventricular injections of mesenchymal stem cells activate endogenous functional remyelination in a chronic demyelinating murine model}

Pablo Cruz-Martinez, Susana González-Granero, María Micaela Molina-Navarro, Jesus Pacheco-Torres, Jose Manuel García-Verdugo, Emilio Geijo-Barrientos, Jonathan Jones and Salvador Martinez

Cell Death and Disease (2017) 8, e2809; doi:10.1038/cddis.2016.340; published online 18 May 2017

Correction to: Cell Death and Disease (2016) 7, e2223; doi:10.1038/cddis.2016.130; published online 12 May 2016
Since publication the authors have noticed the Tercel reference in the acknowledgments section is incorrect. The correct code is RD12/0019/0024. The authors would like to apologise for any inconvenience caused. 